American Journal of Applied Sciences 6 (5): 829-833, 2009

ISSN 1546-9239

(C) 2009 Science Publications

\title{
Enhancing the Urea-N Use Efficiency in Maize (Zea mays) Cultivation on Acid Soils using Urea Amended with Zeolite and TSP
}

\author{
${ }^{1}$ Osumanu Haruna Ahmed, ${ }^{2}$ Aminuddin Hussin, ${ }^{2}$ Husni Mohd Hanif Ahmad, ${ }^{3}$ Mohamadu Boyie Jalloh, \\ ${ }^{2}$ Anuar Abd Rahim and ${ }^{1}$ Nik Muhamad Ab. Majid \\ ${ }^{1}$ Department of Crop Science, Faculty of Agriculture and Food Science, \\ University Putra Malaysia Bintulu Campus, Sarawak, 97008 Bintulu, Sarawak, Malaysia \\ ${ }^{2}$ Department of Land Management, Faculty of Agriculture, University Putra Malaysia, \\ 43400 Serdang, Selangor, Malaysia \\ ${ }^{3}$ School of Sustainable Agriculture, University Malaysia Sabah, Locked Bag 2073, 88999 Kota Kinabalu,
}

Sabah, Malaysia

\begin{abstract}
Problem Statement: Ammonia loss significantly reduces urea-N use efficiency in crop production. Efforts to reduce ammonia loss are laboratory oriented, as such limited in reflecting actual field conditions. This paper reports the effects of urea amended with triple superphosphate (TSP) and zeolite (Clinoptilolite) on soil $\mathrm{pH}$, soil nitrate, soil exchangeable ammonium, dry matter production, $\mathrm{N}$ uptake, fresh cob production and urea-N uptake efficiency in maize (Zea mays) cultivation on an acid soil in actual field conditions. Approach: The treatments evaluated were: (i) Normal N, P, K application (74.34 g urea, 27.36 g TSP, $24.12 \mathrm{~g} \mathrm{KCl)} \mathrm{(T1),} \mathrm{(ii)} \mathrm{Urea-TSP} \mathrm{mixture} \mathrm{(74.34} \mathrm{g} \mathrm{urea}+27.36$ $\mathrm{g}$ TSP) $+24.12 \mathrm{~g} \mathrm{KCl}$ (T2), (iii) $74.34 \mathrm{~g}$ urea+27.36 g TSP+9.0 g zeolite (T3), (iv) $74.34 \mathrm{~g}$ urea $+27.36 \mathrm{~g}$ TSP+13.5 g zeolite (T4) and (v) No fertilization (T5). Note, the same amount of $24.12 \mathrm{~g} \mathrm{KCl}$ was used in T3 and T4 plots. Standard procedures were used to determine the selected chemical properties of zeolite, soil, TSP and urea. The $\mathrm{pH}$ of the urea, zeolite, soil and TSP were determined in a 1:2.5 soil: distilled water suspension and/or $0.01 \mathrm{~N} \mathrm{CaCl}_{2}$ using a glass electrode. The CEC of the zeolite was determined by the $\mathrm{CsCl}$ method. Soil $\mathrm{CEC}$ was determined by leaching with $1 \mathrm{~N}$ ammonium acetate buffer adjusted to $\mathrm{pH} 7.0$ followed by steam distillation. Soil samples at harvest were analyzed for $\mathrm{pH}$ using the method previously outlined. Exchangeable ammonium and nitrate at harvest were extracted from the soil samples by the method of Keeney and Nelson and the amount determined using a LACHAT Autoanalyzer. Total N of the plant tissues (stem and leaf) was determined by the MicroKjeldhal method. Results: Urea amended with TSP and zeolite treatments and Urea only (urea without additives) did not have long term effect on soil $\mathrm{pH}$ and accumulation of soil exchangeable ammonium and nitrate. Treatments with higher amounts of TSP and zeolite significantly increased the dry matter (stem and leaf) production of Swan (test crop). All the treatments had no significant effect on urea-N concentration in the leaf and stem of the test crop. In terms of urea-N uptake in the leaf and stem tissues of Swan, only the treatment with the highest amount of TSP and zeolite significantly increased urea-N uptake in the leaf of the test crop. Irrespective of treatment, fresh cob production was statistically not different. However, all the treatments with additives improved Urea-N uptake efficiency compared to urea without additives or amendment. Conclusion: Urea amended with TSP and zeolite has a potential of reducing ammonia loss from surface-applied urea.
\end{abstract}

Key words: Ammonia volatilization, zeolite, triple superphosphate, urea, urea-N uptake efficiency, soil exchangeable ammonium, nitrate, acid soils, maize cultivation

\section{INTRODUCTION}

Ammonia loss significantly reduces urea-N use efficiency in crop production ${ }^{[1,2]}$. Efforts to reduce ammonia loss are laboratory oriented, as such limited in reflecting actual field conditions. Reduction in urea-N use efficiency in agriculture particularly when urea is surface-applied to soils has been generally associated

Corresponding Author: Osumanu Haruna Ahmed, Department of Crop Science, Faculty of Agriculture and Food Sciences, University Putra Malaysia Bintulu Campus, Sarawak, Malaysia Tel: +6086855406 Fax: +608685415 
with ammonia volatilization and it is thought to be the major pathway for urea-N loss from surface-applied urea $^{[1,2]}$.

Ammonia volatilization in acid soils is generally thought to occur because of high $\mathrm{pH}$ and exchangeable ammonium concentrations in the microsite immediately around the fertilizer ${ }^{[3]}$. In acid soils, triple superphosphate (TSP) has been used to reduce ammonia $\operatorname{loss}^{[3]}$ because it makes the microsite immediately around the fertilizer acidic $^{[3]}$. The high Cation Exchange Capacity (CEC) and great affinity for ammonium ions of humic acids and zeolite have enabled the use of these materials to reduce ammonia volatilization $^{[3-7]}$. The small internal tunnels of clinoptilolite zeolite as an example have been found to physically protect ammonium ions from too much nitrification by microorganisms ${ }^{[8]}$. This process does not only reduce ammonia loss but it also helps in releasing ammonium ions slowly into the soil ${ }^{[9,10]}$. However, it must be stressed that these studies were carried out under laboratory conditions as such the results may not reflect actual field conditions. In view of this, a field study was carried out to evaluate the effects of urea amended with TSP and zeolite on soil $\mathrm{pH}$, soil nitrate, soil exchangeable ammonium, dry matter production (leaf and stem), $\mathrm{N}$ uptake, fresh cob production and urea-N uptake efficiency in maize cultivation in actual field conditions on an acid soil. Positive effects on these variables should lead to reduction in ammonia loss and should in turn improve urea-N use efficiency from surface-applied urea.

\section{MATERIALS AND METHODS}

The study was conducted on a sandy clay loam Typic Kanduidult (Bungor Series) of University Putra Malaysia Agricultural Farm at Puchong. The experimental area has annual precipitation of about 2,200 mm. This area also has a mean monthly maximum and minimum temperature of 32 and $24^{\circ} \mathrm{C}$, respectively and a relative humidity of $70-90 \%$. The Study was carried out between November 2006 and March 2007. The experimental field of the study was a cultivated field that had received little fertilization. The experimental design was a randomized complete block design with three replications (blocks). The plot size within each block was $1.5 \mathrm{~m}$ (length) $\times 1.5 \mathrm{~m}$ (breadth). The distance between plots was $1 \mathrm{~m}$ and that between blocks was $1.5 \mathrm{~m}$. The planting distance was $0.75 \mathrm{~m}$ between rows and $0.25 \mathrm{~m}$ within plants. The $\mathrm{pH}$, Cation Exchange Capacity (CEC), nitrate and exchangeable ammonium of the experimental plots prior to the application of treatments were not different. The treatments evaluated were: (i) Normal N, P, K application (74.34 g urea, $27.36 \mathrm{~g}$ TSP, $24.12 \mathrm{~g} \mathrm{KCl}$ ) (T1), (ii) Urea-TSP mixture (74.34 g urea+27.36 g TSP)+24.12 g KCl (T2), (iii) $74.34 \mathrm{~g}$ urea+27.36 g TSP+9.0 g zeolite (T3), (iv) $74.34 \mathrm{~g}$ urea+27.36 g $\mathrm{TSP}+13.5 \mathrm{~g}$ zeolite (T4) and (v) No fertilization (T5). Note, the same amount of $24.12 \mathrm{~g} \mathrm{KCl}$ was used in T3 and T4 plots. The amounts of urea, TSP and $\mathrm{KCl}$ used were based on the standard recommendation for the test crop (Swan). The zeolite rates were adopted because based on several laboratory trials, they gave better mixtures ${ }^{[5]}$. It must be noted that the rates used in this study were a scale up of our previous laboratory trials. Treatments 3 and 4 were prepared by first weighing the 3 materials (for each treatment) separately into plastic vials. The materials were then transferred into a set of plastic vials, tightly closed and shaken on a reciprocal shaker at $150 \mathrm{rpm}$ for $30 \mathrm{~min}$. to ensure they were uniformly mixed.

Ten Days after Planting (DAP) treatments were applied to the test plants in the plots. At 28 DAP, the treatments were again applied. The plants were monitored and harvested (excluding guard rows) at 90 DAP. The weight of the harvested cobs was taken in situ using a weighing balance. Harvested stems and leaves were oven dried at $60^{\circ} \mathrm{C}$ until constant weight was attained. Afterwards, their weights were also taken by using a weighing balance. Before planting and a day before harvesting, composite soil samples (bulk of 3 samples) were taken at $0-20 \mathrm{~cm}$ in each of the experimental plots using an auger. The soil samples were air dried and ground to pass a $2-\mathrm{mm}$ sieve.

Standard procedures were used to determine the selected chemical properties of zeolite, soil, TSP and urea. The $\mathrm{pH}$ of the urea, zeolite, soil and TSP were determined in a 1:2.5 soil: distilled water suspension and/or $0.01 \mathrm{~N} \mathrm{CaCl}_{2}$ using a glass electrode. The CEC of the zeolite was determined by the $\mathrm{CsCl}$ method $^{[11]}$. Soil CEC was determined by leaching with $1 \mathrm{~N}$ ammonium acetate buffer adjusted to $\mathrm{pH} 7.0$ followed by steam distillation. Soil samples at harvest were analyzed for $\mathrm{pH}$ using the method previously outlined. Exchangeable ammonium and nitrate at harvest were extracted from the soil samples by the method of Keeney and Nelson ${ }^{[12]}$ and the amount determined using a LACHAT Autoanalyzer (LACHAT Instruments, Milwaukee, WI, USA). Total $\mathrm{N}$ of the plant tissues (stem and leaf) was determined by the Micro-Kjeldhal method. Analysis of variance was conducted to test for treatment effect while means of treatments were compared using Tukey's test. Urea-N use efficiency was calculated according to the formula ${ }^{[13]}$ : 
Am. J. Applied Sci., 6 (5): 829-833, 2009

$\%$ fertilizer nutrient recovery $=\frac{(\mathrm{TNF})-(\mathrm{TNU})}{\mathrm{R}} \times 100$

Where:

$\mathrm{TNF}=$ Total nutrient uptake from fertilized plots

$\mathrm{TNU}=$ Total nutrient uptake from unfertilized plots

$\mathrm{R}=$ Rate of fertilizer nutrient applied

\section{RESULTS}

The soil $\mathrm{pH}$ (water; 1:2.5 soil: Distilled water suspension), $\mathrm{pH}\left(0.01 \mathrm{~N} \mathrm{CaCl}_{2}\right)$ and $\mathrm{CEC}$ before planting were $4.50,4.00$ and $6.40 \mathrm{cmol} \mathrm{kg} \mathrm{kg}^{-1}$, respectively. These results were consistent with those reported in the literature. The $\mathrm{pH}$ (water), $\mathrm{pH}(0.01 \mathrm{~N}$ $\left.\mathrm{CaCl}_{2}\right)$ and $\mathrm{CEC}$ of zeolite were $6.10,5.30$ and 105 $\mathrm{cmol} \mathrm{kg}^{-1}$, respectively and they were also comparable with those reported by Ahmed et al. ${ }^{[14]}$ who also provided other properties of this zeolite. Irrespective of treatment, the soil $\mathrm{pH}$ (water), $\mathrm{pH}\left(0.01 \mathrm{~N} \mathrm{CaCl}_{2}\right)$, exchangeable ammonium and nitrate at harvest were not significantly different at $\mathrm{p}=0.05$ (Table 1 ). This observation is consistent with the finding of a study that evaluated these treatments on Bungor Series cultivated with a maize variety called Putra J-56 ${ }^{[15]}$, suggesting that $T_{2}, T_{3}$ and $T_{4}$ have no long term effect in controlling the release of these nutrients under field conditions.

Compared to $\mathrm{T}_{5}, \mathrm{~T}_{3}$ and $\mathrm{T}_{4}$ (treatments with higher amounts of TSP and zeolite) significantly increased the dry matter production (stem and leaf) of the test crop (Table 2). In a related field study, urea with the highest amount of additives significantly increased the stem and leaf dry weight of Putra J-56 maize variety ${ }^{[15]}$. All the treatments had no significant effect on the urea-N concentration in the leaf and stem of the test crop while in terms of urea- $\mathrm{N}$ uptake in these parts, only $\mathrm{T}_{4}$ significantly increased urea-N uptake in the leaf of the crop (Table 3 and 4).

Irrespective of treatment, fresh cob production was statistically not different (Table 5) but in terms of efficiency, $\mathrm{T}_{2}, \mathrm{~T}_{3}$ and $\mathrm{T}_{4}$ improved urea-N uptake efficiency (Table 6).

Table 1: Soil $\mathrm{pH}$, soil nitrate and soil exchangeable ammonium at 90 Days after planting (DAP)

\begin{tabular}{lllll}
\hline Treatment & $\mathrm{pH}_{(1 \mathrm{NKCl})}$ & $\mathrm{pH}_{(\text {water })}$ & $\mathrm{NO}_{3}(\mathrm{ppm})$ & $\mathrm{NH}_{4}(\mathrm{ppm})$ \\
\hline $\mathrm{T}_{1}$ & 3.86 & 5.09 & 7.97 & 609 \\
$\mathrm{~T}_{2}$ & 3.79 & 5.18 & 7.77 & 563 \\
$\mathrm{~T}_{3}$ & 3.83 & 5.09 & 7.77 & 653 \\
$\mathrm{~T}_{4}$ & 3.88 & 5.30 & 7.93 & 544 \\
$\mathrm{~T}_{5}$ & 3.93 & 5.50 & 5.80 & 470 \\
\hline
\end{tabular}

Table 2: Dry weight of stem and leaf of Swan at 90 DAP

\begin{tabular}{|c|c|c|}
\hline Treatment & Stem g plant $^{-1}$ & Leaf g plant $^{-1}$ \\
\hline$\overline{\mathrm{T} 1}$ & $156.60^{\mathrm{bc}}$ & $58.27^{\mathrm{abc}}$ \\
\hline $\mathrm{T} 2$ & $127.45^{\mathrm{bc}}$ & $49.89^{\mathrm{bc}}$ \\
\hline T3 & $164.74^{\mathrm{ab}}$ & $93.27^{\mathrm{a}}$ \\
\hline T4 & $203.51^{\mathrm{a}}$ & $85.89^{\mathrm{ab}}$ \\
\hline T5 & $123.01^{\mathrm{c}}$ & $36.32^{\mathrm{c}}$ \\
\hline \multicolumn{3}{|c|}{$\begin{array}{l}\text { Note: Different alphabets within column indicate } \\
\text { difference between means using Tukey's test at } p=0.05\end{array}$} \\
\hline Treatment & Stem (\%) & Leaf (\%) \\
\hline T1 & 0.83 & 0.24 \\
\hline $\mathrm{T} 2$ & 1.37 & 0.27 \\
\hline $\mathrm{T} 3$ & 1.13 & 0.21 \\
\hline $\mathrm{T} 4$ & 1.35 & 0.25 \\
\hline T5 & 1.13 & 0.19 \\
\hline
\end{tabular}

Table 4: Urea-uptake in leaf and stem of Swan at 90 DAP

\begin{tabular}{lll}
\hline Treatment & Leaf g plant $^{-1}$ & Stem g plant $^{-1}$ \\
\hline $\mathrm{T}_{1}$ & $0.14^{\mathrm{ab}}$ & 1.30 \\
$\mathrm{~T}_{2}$ & $0.13^{\mathrm{ab}}$ & 2.38 \\
$\mathrm{~T}_{3}$ & $0.19^{\mathrm{ab}}$ & 2.03 \\
$\mathrm{~T}_{4}$ & $0.24^{\mathrm{a}}$ & 2.34 \\
$\mathrm{~T}_{5}$ & $0.08^{\mathrm{b}}$ & 1.29 \\
\hline
\end{tabular}

Note: Different alphabets within column indicate significant difference between means using Tukey's test at $p=0.05$

Table 5: Fresh cob yields of Swan at 90 DAP

\begin{tabular}{ll}
\hline Treatment & kg ten plant \\
\hline $\mathrm{T}_{1}$ & 3.38 \\
$\mathrm{~T}_{2}$ & 3.37 \\
$\mathrm{~T}_{3}$ & 3.48 \\
$\mathrm{~T}_{4}$ & 3.42 \\
$\mathrm{~T}_{5}$ & 3.00 \\
\hline
\end{tabular}

Table 5: Fresh cob yields of Swan at 90 DAP

\begin{tabular}{ll}
\hline Treatment & kg ten plant \\
\hline $\mathrm{T}_{1}$ & 3.38 \\
$\mathrm{~T}_{2}$ & 3.37 \\
$\mathrm{~T}_{3}$ & 3.48 \\
$\mathrm{~T}_{4}$ & 3.42 \\
$\mathrm{~T}_{5}$ & 3.00 \\
\hline
\end{tabular}

Table 6: Urea-N uptake Efficiency at 90 DAP

\begin{tabular}{llcc}
\hline Treatment & Leaf $(\%)$ & Stem $(\%)$ & Total $(\%)$ \\
\hline $\mathrm{T}_{1}$ & 0.79 & 0.18 & 0.97 \\
$\mathrm{~T}_{2}$ & 0.67 & 13.50 & 14.17 \\
$\mathrm{~T}_{3}$ & 0.79 & 9.00 & 9.79 \\
$\mathrm{~T}_{4}$ & 1.79 & 13.00 & 14.79 \\
$\mathrm{~T}_{5}$ & na & na & na \\
\hline
\end{tabular}

Na: not applicable

\section{DISCUSSION}

In one of our laboratory studies on the effect urea amended with TSP and zeolite, we found significant accumulation of ammonium at only $0-3 \mathrm{~cm}$ only after 15 days of incubation ${ }^{[7]}$. We found no significant accumulation of ammonium at $3-7.5 \mathrm{~cm}$ while for 
nitrate, regardless of soil depth, there was no significant accumulation irrespective of treatment $t^{[7]}$. In the case of $\mathrm{pH}$, our laboratory study results also indicated no significant effect regardless of treatment and soil depth after 15 days of incubation ${ }^{[7]}$. The $\mathrm{pH}$ of the TSP was 2.50 and was considered low. This may be partly attributed to the acceptable amounts of $\mathrm{K}, \mathrm{Ca}$ and $\mathrm{Mg}$ in the $\mathrm{TSP}^{[5]}$. The $\mathrm{pH}$ of the urea was 8.00 and it was also considered high.

Contrary to our study, urea with the highest amount of additives significantly increased the stem and leaf dry weight of Putra J-56 maize variety ${ }^{[15]}$. This could be attributed to varietal difference.

It is interesting to note that the under $\mathrm{T}_{1}$ (urea without additives) the overall urea-N use efficiency only $1 \%$ only while those under $\mathrm{T}_{2}, \mathrm{~T}_{3}$ and $\mathrm{T}_{4}$ (urea with additives) were approximately 14, 10 and 15\%, respectively. Based on the climatic information provided, perhaps the additives of these treatments may have caused a temporary reduction in ammonia loss at the initial stages of the application of the treatments compared to $\mathrm{T}_{1}$.

\section{CONCLUSION}

Compared to $T_{5}, T_{3}$ and $T_{4}$ significantly increased the dry matter production Swan. In terms of urea-N uptake in the leaf and stem tissues, only $\mathrm{T}_{4}$ had significant effect on urea-N uptake in the leaf of the test crop. Irrespective of treatment, fresh cob production was statistically not different. However, all the treatments with additives improved urea-N efficiency compared to urea without additives or amendment. This suggests that urea amended with TSP and zeolite has the potential of reducing ammonia loss from surfaceapplied urea. Hence could contribute to reduction of environmental pollution particularly in relation to urea use in agriculture.

\section{ACKNOWLEDGMENT}

The authors are grateful to PETRONAS for financial and technical collaboration.

\section{REFERENCES}

1. Prasertsak, P., J.R. Freney, P.G. Saffiga, O.T. Denmead and B.G. Prove, 2001. Fate of urea nitrogen applied to a banana crop in the wet tropics of Queensland. Nut Cycl. Agroec., 59: 65-73. http://www.springerlink.com/content/j266309w2u5 65873/fulltext.pdf
2. Cai, G.X., D.L. Chen, H. Ding, A. Pacholski, X.H. Fan and Z.L. Zhu, 2002. Nitrogen losses from fertilizers applied to maize, wheat and rice in the North China Plan. Nut Cycl. Agroec., 63: 187-195. http://www.springerlink.com/content/n3146826u27 87674/fulltext.pdf

3. Fan, M.X. and A.F. Mackenzie, 1993. Urea and phosphate interactions in fertilizer microsites: Ammonia volatilization and $\mathrm{pH}$ changes. Soil Sc. Soc Am. J., 57: 839-845. http://soil.scijournals.org/

4. Siva, K.B., H. Aminuddin, M.H.A Husni and A.R. Manas, 1999. Ammonia volatilization from urea as affected by tropical-based palm oil palm effluent (pome) and peat. Comm. Soil Sci. Plant Anal., 30 785-804. DOI: $10.1080 / 00103629909370246$

5. Ahmed, O.H, H. Aminuddin and M.H.A. Husni, 2006a. Reducing ammonia loss from urea and improving soil exchangeable ammonium retention through mixing triple superphosphate, humic acid and zeolite. Soil Use Manage., 22: 315-319. DOI: 10.1111/j.1475-2743.2006.00040.x

6. Ahmed, O.H, H. Aminuddin and M.H.A. Husni, 2006b. Effects of urea, humic acid and phosphate interactions in fertilizer microsites on ammonia volatilization and soil ammonium and nitrate contents. Int. J. Agric. Res., 1: 25-31. $\mathrm{http} / / /$ scialert.net/archivedetails.php?issn=18164897\&issueno $=19$

7. Ahmed, O.H, H. Aminuddin and M.H.A. Husni, 2008. Ammonia volatilization and ammonium accumulation from urea mixed with zeolite and triple superphosphate. Acta Agric. Scandinavica Section B, Soil Plant Sci., 58: 182-186. DOI: 10.1080/09064710701478271

8. Ferguson, G.A. and G. Pepper, 1987. Ammonium retention in sand amended with clinoptillolite. Soil Sci. Soc. Am. J., 54: 1316-1323. http://soil.scijournals.org/

9. Kithome, M., J.W. Paul, L.M. Lavkulich and A.A. Bomke, 1998. Kinetics of ammonium adsorption and desorption by the natural zeolite clinoptilolite. Soil Sci. Soc. Am. J., 62: 622-629. http://soil.scijournals.org/

10. Amon, M., M. Dobeic, R.W. Sneath, V.R. Philips, T. Misselbrook and B.F. Pain, 1997. A farm scale study on the use of clinoptilolite zeolite and deBodorase for reducing odor and ammonia emissions from broiler houses. Bioresour. Technol., 61: 229-237. DOI: 10.1016/S09608524(97)00005-9

11. Ming, D.W. and J.B. Dixon, 1986. Clinoptilolite in South-Texas soils. Soil Sci. Soc. Am. J., 50: 1618-1622. http://soil.scijournals.org/ 
12. Keeney, D.R. and D.W. Nelson, 1982. NitrogenInorganic Forms. In: Methods of Soil Analysis, Part 2. 2nd Edn., Page, A.L., D.R. Keeney, D.E. Baker, R.H. Miller, Jr. R. Ellis and J.D. Rhoades (Eds.). Madison, W.I. Agron. Monogr. 9. ASA and SSSA., ISBN: 0891180729.

13. Pomares-Gracia, F. and P.F. Pratt, 1978. Recovery of ${ }^{15} \mathrm{~N}$-Labelled fertilizer from manure and sludgeamended soils. Soil Sci. Soc. Am. J., 42: 717720. http://soil.scijournals.org/

14. Ahmed, O.H, H. Aminuddin and M.H.A. Husni, A. Rahim and Majid N.M.A. 2008. Enhancing the urea-n use efficiency in maize (Zea mays) cultivation on acid soils amended with zeolite and TSP. The Sci. World J. UK., 8: 394-399. DOI:10.1100/tsw.2008.68.
15. Ahmed, O.H., H. Aminuddin, M.H.A. Husni and A.R. Anuar, 2007. Effect of Urea Coated with Humic Acid and Triple Superphosphate on Maize Dry Matter Production, Soil Nitrate, Ammonium and $\mathrm{pH}$. In: Proceedings Soils, Hamdan, J., K.H. Goh, C.I. Fauziah, M. Lulie, O.H. Ahmed, M.B. Jalloh, A. Sayok and B. Siva (Eds.). Malaysian Society of Soil Science, Serdang, Malaysia, ISBN: 9789679945294 (pbk), pp: 209-221. 